\title{
Disaster Management Measures Adopted at Schools in Alexandria
}

\author{
Shaymaa Saeed Mohamed Badawy, Assistant Lecturer \\ Community Health Nursing, Faculty of Nursing, Alexandria University
}

\author{
Alyaa Farouk Abd El-Fattah Ibrahim, Lecturer \\ Community Health Nursing, Faculty of Nursing, Alexandria University \\ Zakia Toma Yousef Toama, Professor \\ Community Health Nursing, Faculty of Nursing, Alexandria University
}

\begin{abstract}
The concept of school safety is not limited to preventing the collapse of school buildings in disasters, and safety of teachers and students, but rather extends to meet the broader goal "disaster risk management". Objective: The present study aimed to assess the disaster management measures adopted at schools in Alexandria, and to identify knowledge and practice of disaster and crisis committee members' about school disaster and crisis management plan and it's measures. Setting: Twenty one governmental schools affiliated to Ministry of education in Alexandria Governorate were included in the study. Subjects: The study comprised 110 members of the selected schools' disaster and crisis committees. Tools: Three tools were utilized for data collection; Socio demographic characteristics and school record review for disaster management plan questionnaire, knowledge of committee members related to disaster management plan questionnaire and committee member's practices related to disaster management questionnaire. Results: The study revealed that all assessed schools had disaster and crisis management plan, the majority of the members of the crisis and disaster committee were not oriented with its content, never dealt with any emergency, never checked on the emergency equipment placed, and most significantly, the available plans were not suitable in different emergency situations. Conclusion: It could be concluded that all assessed schools had disaster and crisis management plan. The majority of the study sample obtained unsatisfactory score for their knowledge and practice related to disaster and disaster management. The low score reflects deficiencies in all assessed aspects of information; lack of knowledge, lack of training and absence of motivation. Recommendations: A comprehensive standardized national preventive strategies for achieved safety measures in schools should be developed and implemented.
\end{abstract}

Keywords: Disaster management, school safety, school disasters.

\section{Introduction}

Disaster is any occurrence that causes damage, ecological disruption, loss of human life, deterioration of health and health services on a scale sufficient to warrant an extraordinary response from outside the affected community ${ }^{(1)}$. There are two types of disasters-Manmade and Natural.

Natural disasters are events caused by natural forces of nature that often have a significant effect on human population (e.g. flood, tornado, hurricane, volcanic eruption, earthquake or landslide) that affects the environment, and leads to financial, environmental and/or human losses, typically human population either is displaced (left homeless) or killed ${ }^{(2-4)}$.

However, man-made disasters are those caused directly and principally by one or more identifiable deliberate or negligent human actions, also called human-made disaster. Manmade disasters cover a wide 
range of events created largely due to accidents, negligence or sometimes even by human design, which result in huge loss of lives. These include road, rail, river, marine and aviation accidents, oil spill, building and bridge collapse, bomb blast, industrial and chemical accidents etc., these also include the threats of nuclear, biological and chemical disasters $^{(1-5)}$.

Children and young people are extremely vulnerable when disaster strikes. Since the year 2000, in only 8 major disasters in El Salvador, Venezuela, Italy, Turkey, Cambodia, USA, Pakistan and China; more than 28,000 children and teachers lost their lives in unsafe school buildings ${ }^{(6-8)}$.

Egypt has not experienced any largescale disaster for many years; although, the country is located on a fault line which could be disrupted by an earthquake or severe weather changes ${ }^{(9)}$. October 1992 earthquake resulted in the collapse of 6987 educational institutions full-or part after the breakdown. Moreover, November 1994 flood that swept Upper Egypt resulted in the collapse of 33 schools and the Azhari Institute in addition to partial collapse of 146 educational facilities ${ }^{(9,10)}$.

Schools play a key role in taking preventative and protective measures to stop an emergency from occurring or reduce the impact of an incident. Although, schools are entrusted to provide a safe and healthy learning environment for school students. Lessons learnt from school emergencies highlight the importance of preparing school officials and first responders to implement emergency operation plans ${ }^{(4-6)}$. So, every school needs a crisis plan that is tailored to its unique characteristics. Within a school district, however, it is necessary for all plans to have certain commonalities ${ }^{(5,6,10)}$. School nurses are the link to local public health departments and emergency services, and it is imperative that school nurses be familiar with this standardized common language provided through the federal government agencies.
They serve as conduits for dissemination of public health information to students and families and liaison with emergency medical services to plan for a potential mass casualty event and provide care for students in the event of emergency illness or injury $^{(11-12)}$.

School nurses are strategically placed within school environments and can identify potential emergencies and assist in planning a comprehensive and coordinated response. As licensed health care professionals, they respond to all serious adverse events that threaten the health, safety, or well-being of a school population. School nurses, as advocates for school safety, must address new challenges in emergency management and response and establish their vital role before, during, and after a disaster, addressing the needs of all members of the school community ${ }^{(13)}$.

\section{Aim of the Study}

To assess the disaster management measures adopted at schools in Alexandria, and to identify knowledge and practice of disaster and crisis committee members' about school disaster and crisis management plan and it's measures.

\section{$\underline{\text { Research Questions: }}$}

What are the measures adopted at schools to manage disasters? And what are schools' disaster and crisis committee members' knowledge and practice regarding school disaster and crisis management plan and it's measures?

\section{Materials and Method}

\section{Materials}

Design: A descriptive research design was used in this study.

Setting: Multistage random sampling technique was used accordingly at all (seven) educational zones affiliated to Alexandria Governorate namely: El 
Montazah, East, Middle, West, El Gomrok, El Amria, and Borg El Arab. Three schools were selected randomly from each zone: one primary, one preparatory and one secondary. This gave a total number of 21 governmental schools affiliated to Ministry of Education in Alexandria Governorate that were included in the study.

Subjects: The subjects of this study included all (210) members of the selected schools' disaster and crisis committees.

Tools: Three tools were developed and used by the researcher based on the review of related literature for the purpose of data collection:

Tool I: Socio demographic characteristics and school record review for disaster management plan questionnaire

Includes 3 parts:

Part 1: Socio demographic characteristics of the school crisis and disaster committee members: age, sex, position, qualification, etc.

Part 2: School record review for disaster management plan design, characteristics and safety measures: it includes the following items: Presence of the plan, committee composition and roles of members, school building design and plan for evacuation in case of disaster.

Part 3: Observation checklist for school building and classroom characteristics and environment safety: it includes: presence of engineering drawing, emergency exit stairs, minimal number of entrances, presence of fence, building design, stairs, electricity hazards, no smoking signs, emergency exit signs, health awareness posters, booklet explaining safety and security, waste disposal. Classroom characteristics; lighting, ventilation, window curtains and safety slides, etc. The answer for each item was either "present" or "not present".
Tool II: knowledge of committee members related to disaster management plan questionnaire

It includes general information about disaster, knowledge about fire, firefighter, first aid, etc. The answer for each item was either "Yes", "No", "I don't know" or "not applicable". A score "one" was given to the correct answer and "zero" was given to wrong answer, missing answer and don't know. "Not applicable" answer was removed from the score. The answers of the committee members were recorded, scored then summed together. The total score was categorized into two levels. These levels were satisfactory and unsatisfactory answers.

Tool III: Committee member's practices related to disaster management questionnaire

It includes: activities done by the committee, school environment inspection, inspection frequency, inspection report, maintenance, emergency evacuation plan, hazards at school, etc. The answer for each item was either "Yes", "No", "I don't know" or "not applicable". A score "one" was given to the correct answer and "zero" was given to wrong answer, missing answer and don't know. "Not applicable" answer was removed from the score. The answers of the committee members were recorded, scored then summed together. The total score was categorized into two levels. These levels were satisfactory, and unsatisfactory answers.

\section{Method}

- An official letter from the Faculty of Nursing was directed to:

- The Packing and Statistics Center in Cairo to seek the permission for conducting the study.

- The Ministry of Education in Alexandria governorate to seek the permission for conducting the study. 
- The Educational Districts in Alexandria governorate sent an official letter to the director of each school included in the study to inform them about Ministry of Education's permission and seek their cooperation.

- Tools were developed by the researchers after extensive review of relevant and current literature. Comments and suggestions of jury were considered and the tools were modified accordingly.

- The validity and domain representatives of the instruments developed were ascertained by asking five experts to evaluate the instrument.

- Internal consistency was used in ascertaining reliability of the instrument using Cronbach Alpha Cofficient Test (7.4).

\section{- Pilot study:}

- Tools were pre-tested on thirty personnel of schools' crisis and disaster committees from Zein El abdeen primary school, El Zahraagirls preparatory school and NabawiaMousa girls secondary school which were not included in the original study subjects.Data obtained from the pilot study was analyzed and accordingly some questions were restated and some items were added.

\section{- Data collection:}

- Each member was interviewed individually after brief explanation of the aim of the study. The interview took about 30 minutes for each person.

- Data was collected over a period of 7 months starting from November 2012 to May 2013.

\section{Ethical considerations:}

- Members in the Committee for Disaster and Crisis (study participants) were approached and given a covering letter preceded the questionnaire included a written description of the purpose and nature of the study then a written consent to participate in the study was obtained from them.

- The assurance of anonymity was addressed prior to a request for participation. Anonymity of participants was provided in two ways: members in the Committee for Disaster and Crisis were asked not to put their names on the questionnaire, thus all information was remained confidential. In addition, members in the Committee for Disaster and Crisis were reassured that their participation in the study was voluntary. All potential members in the Committee for Disaster and Crisis were informed that they could withdraw from the study at any time if they wish not to participate, by returning the unanswered questionnaire during collection of answers.

- Confidentiality was maintained by data coding to eliminate identifying data with personal information.

\section{Statistical Analysis}

After data collection, it was coded and transferred into a specially designed format to be suitable for computer feeding. Following data entry, checking and verification process were carried out to avoid any error during data entry.

Statistical analysis was performed using Statistical package for Social Sciences (SPSS version 20) and tabulated. The level of significance selected for this study was $p$ equal to or less than 0.05 . 


\section{The following statistical measures were used:}

- Descriptive measures included: count and percentage used for describing and summarizing variables. Arithmetic means, standard deviation, range (maximum and minimum) were used as measures of control tendency and dispersion respectively for normally distributed quantitative data.

- Statistical tests included: chi square test $\left(\chi^{2}\right)$ was used to test the association between the categories.

- A scoring system was created for evaluating knowledge about disaster and disaster management of the crisis and disaster committee personnel as follows:

- Satisfactory level: equal \& more than $85 \%$.

- Unsatisfactory level: less than $85 \%$.

- A scoring system was created for evaluating activities and safety measures practice by the crisis and disaster committee personnel as follows:

- Satisfactory level: equal \& more than $75 \%$.

- Unsatisfactory level: less than $75 \%$.

\section{Results}

Table (1) shows that the age of the studied group ranged between 23 and 59 years with a mean age of $46.5 \pm 7.52$ years. Males represented two thirds $(66.2 \%)$ of the studied sample. More than two thirds $(66.7 \%)$ of the studied sample were university graduates, about one third $(31.9 \%)$ had diploma, while; only $1.4 \%$ had post graduate degree. Concerning committee composition (jobs at their schools); teachers constituted the highest percentage $(79.5 \%)$, followed by head masters, assistant head masters, and nurses of equal percentage $(3.8 \%)$, and social workers, lab technicians, workers, psychologists and administrative employees $(3.3 \%, 2.9 \%, 1.4 \%, 1.0 \%$ \& $0.5 \%$, respectively).

Concerning the duration of membership in the committee, almost half $(49.5 \%)$ the study sample had one to four years duration, followed by more than one third $(34.8 \%)$ of them had one year duration, less than two fifths $(14.3 \%)$ of them had five to ten years duration, and only $1.4 \%$ had membership duration more than ten years. Considering topics of training which committee members attended, more than half of the committees' members received training about the evacuation plan and utilization of fire extinguisher $\quad(52.9 \%$ \& $54.3 \%$, respectively). Nonetheless, the reaming hold received training about chemical substance precautions, C.P.R., using alarm system, fire management, crisis and disaster management, and first aid $(5.7 \%, 11.4 \%$, $18.1 \%, \quad 24.8 \%, \quad 24.8 \%$ \& $35.2 \%$, respectively). The table also depicts that more than half $(52.4 \%)$ the study sample mentioned that evacuation training never been done at their schools, more than two thirds $(36.7 \%)$ of them had the evacuation training performed once per academic semester at their schools, and $11 \%$ of them had the evacuation training performed twice per academic semester.

Table (2) demonstrates that less more than one quarter $(28.6 \%)$ of the assessed schools had engineering drawing for the school, about one fifth $(19.0 \%)$ of them lack the emergency exit stairs. Almost one quarter $(23.8 \%)$ of the observed schools lack the minimal of two entrances, in addition to, more than three quarters (76.2\%) of them do not have the building design utilities for people with disabilities. Meanwhile, all (100\%) observed schools had a fence around them. 
It's apparent from the table that, more than two fifth equal percentage $(42.9 \%)$ of the observed schools had unsafe stairs without handrail, electricity contacts are not fixed, and electricity hazardous areas are not separate and opened. While, only $52.4 \%$ had "no smoking" signs distributed in all areas of the school buildings, only $33.3 \%$ of the assessed schools had signs to guide the students for emergency exits.

The table also shows that all observed schools $(100 \%)$ had posters to disseminate health messages for students. Meanwhile, all assessed schools (100\%) lack the booklet explaining safety, security and evacuation procedures, Nevertheless, the majority $(90.5 \%)$ of the assessed school buildings' dispose waste daily. All (100\%) classrooms in the observed schools were clean and had wastepaper baskets. However, less than three quarters equally $(71.4 \%)$ had natural light, were well ventilated and had posters to disseminate health messages for students inside the classrooms.

Lastly, it can be observed from the table that the majority $(81 \%)$ of the observed classrooms lack artificial light apparatus, all $(100 \%)$ of them didn't have curtains on widows to protect students from sunrays, and only $19 \%$ of the classrooms had safety slides placed on the upper windows.

Table (3) presents that less than half $(47.6 \%)$ the assessed schools had evacuation plan that had been revised yearly, and only $19 \%$ of the schools had emergency plans that deals with various situations. However, slightly more than one quarter $(28.6 \%)$ of the emergency plans had the names of the crisis and disaster committee members clearly shown on them, and two thirds $(66.7 \%)$ of them determined the equipment needed in case of emergency.

Nevertheless, $57.1 \%$ of the assessed plans identified the evacuation routes and assembling areas, also had the student's training on the evacuation (drill) mentioned, but less than half $(47.6 \%)$ the assessed schools had their emergency plan distributed in different areas. The table also presents that, most of the assessed schools had signs showing the emergency exits and had the exit routes free from obstructions (81\% \& $85.7 \%$, respectively). Fire alarm was found to be working properly in two thirds $(66.7 \%)$ of the assessed schools, and could be heard in all school areas in less than two thirds $(61.9 \%)$ of them.

The table also clarifies that more than two fifth $(42.9 \%)$ of the observed schools lack the reporting person at the assembling area, and only one third (33.3\%) of them had the first aid kit available at the assembling area, more than one quarter (28.6\%) had the first aid kit available inside the classrooms, despite of, the vast majority $(95.2 \%)$ of them had the first aid kit complete and ready to use at the school clinics. Consequently, only one third $(33.3 \%)$ of the observed schools register their visitors daily

Table (4) presents that only $2.4 \%$ of the study subjects obtained satisfactory score concerning their knowledge about disaster and disaster management. The table also highlights statistically significant differences observed between the crisis and disasters committee members concerning their knowledge about general information about fire \& it's management, risk and types of fire, and disaster management before, during and after the crisis $\left(\chi^{2}=12.469\right.$, $\mathrm{P}=0.000, \quad \chi^{2}=5.122, \quad \mathrm{P}=0.024, \quad \chi 2=6.452$, $\mathrm{P}=0.011, \quad \chi^{2}=4.656, \quad \mathrm{P}=0.031, \quad \chi^{2}=5.122$, $\mathrm{P}=0.024 \quad \& \quad \chi^{2}=5.025, \quad \mathrm{P}=0.025$, respectively).

Table (5) shows that the lowest percentages of shows high statistically significant differences between the disaster and crisis committee members from different educational zones concerning; their knowledge related to all assessed disaster and disaster management topics except, type of disasters, phases of disaster management, general information about fire, it's management, and disaster management after the crisis $\left(\chi^{2}=10.56 \&\right.$ $\mathrm{P}=0.103, \chi^{2}=10.53 \& \mathrm{P}=0.103, \chi^{2}=19.50 \&$ 
$\mathrm{P}=0.077, \chi^{2}=10.90 \& \mathrm{P}=0.09, \chi^{2} \mathrm{a}=4.64 \&$ $\mathrm{P}=0.59$ ).

Table (6) clarifies that knowledge of the crisis and disaster committee about their duties when compared by school stages, districts, age groups, gender and level of education didn't show any statistical difference between them, except for the level of education of teachers and social workers that was significantly associated $\left(\chi^{2}=7.347 \& \mathrm{P}=0.025\right)$.

Table (7) reveals that only $7.6 \%$ of the study subjects obtained satisfactory score concerning their practice of activities and safety measures. The table also reveals statistically significant differences observed between the disasters and crisis committee members concerning their practice of all activities and safety measures except for the inspection report to responsible members, emergency evacuation plan, hazards present at the school and in case of armed robbery or shooting that were not significant $\left(\chi^{2}=1.119 \& \mathrm{P}=0.290, \chi^{2}=1.370 \& \mathrm{P}=0.242\right.$, $\left.\chi^{2}=1.676 \& \mathrm{P}=0.195, \chi^{2}=2.960 \& \mathrm{P}=0.085\right)$.

\section{Discussion}

School constitutes an environment of public health concern since it is the location of occurrence of a major proportion of disasters sustained by children who ought to be protected and simultaneously, their knowledge on disasters needs to be increased $^{(14)}$. Studies of disaster trends and the likely consequences of climate change suggest that each year 175 million children are likely to be affected by natural hazards related disasters alone ${ }^{(15)}$.

Despite of all the international efforts on disaster reduction in the educational sector in the context of children rights, there is no major educational program related to disaster risk reduction (DRR) in the Egyptian schools. Thus teaching DRR in schools will help raise awareness and give better understanding not limited to children and teachers, but to the community ${ }^{(16-18)}$. At the same time, investing more in strengthening school-building structures before disasters take place would help reduce long term costs, protect children, and ensure educational continuity after the event $^{(16-19)}$.

Responsibility for maintenance of school physical infrastructure and nonstructural safety must be established by school authorities with mechanisms for financing and execution ${ }^{(20)}$. Education authorities and schools should have practice, policies and procedures for expected disasters and emergencies ${ }^{(16)}$. These include standard operating procedures for fire and other fast and slow onset hazards.

Findings of this study depicts that about one quarter of the assessed schools lack the engineering drawing for the school, with no emergency exit stairs, and don't meet the minimal of two school entrances. In addition, almost half the number of the observed schools had broken stairs, without handrails, and had the electricity contacts not fixed and the electricity hazardous areas not separate and opened. Those results came in accordance with Helal (2005), who mentioned in her study that nearly one quarter of old school buildings needed repair, nearly one fifth of school stairs and half of their rails needed repair in all observed schools in her study, posing great risk for student's health and safety ${ }^{(21)}$.

Capacity buildings, through the limited available resources were a continuous practice in Egypt, either at national or local governorates level ${ }^{(18)}$. While, considering financial constraints and sometimes limitation in human resources, enhanced capacities at all levels to monitor and respond to potential disaster and environmental risks should be dealt with as ongoing practice ${ }^{(19,20)}$.

It is important that all school personnel working with students should be involved in comprehensive safety in-service training programs because safety training is an integral part of a successful safety 
$\operatorname{program}^{(22)}$. The present study revealed that the majority of the committee members didn't obtain any comprehensive safety training, but received several other topics as using alarm system, first aid, fire management, chemical substance precaution and crisis and disaster management. This result may be due to lack of financial resources or the shortage in specialized personnel to conduct this training for school staff. Also it was reported that the training was allowed only for one person who was responsible for emergency or quality management in the school.

It is worthy to note, that all observed schools did not have any booklet explaining the safety, security \& evacuation procedures, and they even lack the availability of very simple measures like curtains on window to protect students from sunrays. However, more than one third of them had emergency exit signs to guide students for pass way for exit. This might be a result of lack of awareness of the school staff about the importance of such signs.

Community awareness of the school district's disaster plan will optimize a community's capacity to maintain the safety of its school-aged population in the event of a school-based or greater community crisis. All health care professionals, the media, school staff, and parents need to be unified in their efforts to support schools in the prevention of, preparedness for, response to, and recovery from a disaster ${ }^{(22)}$.

However, results of the present study revealed that in spite of the majority of the observed schools had disaster management plan, all members of the crisis and disaster committee were not oriented with its content, never dealt with any emergency situation, never checked on the emergency equipment placed in the plan, and most significantly is that, the available plans were not suitable in different situations of the different schools. Moreover, the names of the team members in the disaster committee were not known to all school staff, also, the plan was not reviewed every year, and it never been previously applied.

Regarding safety measures in schools, the presence of complete first aid boxes and the availability of skilled teacher or social workers may reduce the severity of several injuries and save the life of students especially in case of fire or disaster and in the absence of school health team. The first aid boxes should be located in critical area of schools ${ }^{(23)}$. In the present study, it was noted that the majority of the included schools had lack the first aid kits at the assembling areas and the classrooms, and that they were located mostly complete and ready to use inside the schools' clinics.

Assessing the practice of all members of the school disaster and crisis committee concerning activities and safety measures adopted, showed statistically significant differences between the disasters and crisis committee personnel from all schools concerning their practice in all activities and safety measures adopted except for the inspection report to responsible personnel, emergency evacuation plan, hazards present at the school and in case of armed robbery or shooting that were not significant. It is worthy to note, that less than one quarter of the disaster and crisis committee personnel in this study received comprehensive crisis and disaster management training. Additional possible reason for the very few percent of satisfactory score of performance might be related to lack of knowledge, lack of experience and lack of motivation to the personnel. This result was concurrent with the findings revealed by Mamogale (2011) who reported that the vast majority of his study subjects did not attend any training or workshop on disaster management ${ }^{(24)}$.

Data of the current study showed high significant differences between answers given by the disaster and crisis committee personnel from different educational zones concerning; definition of disaster, risk of fire, types of fire, mean of firefighting, fire fighters theory, contents of the first aid kit, goal of crises and disaster committee, 
responsibilities of crises and disasters team's, disaster management before the crisis and disaster management during the crisis. Results of this study reported that East, West, Middle and Montaza zones present high practice score and more knowledgeable staff about disaster management and more oriented committee work than in Borg El Arab, Amria and El Gomrouk zones. On the other hand, Borg El Arab and Amria zones present the new school buildings, follow standards of building emergency and availability of wide area with low school capacity, but inactive drill and material of emergency, and no maintenance compared to other zones as East, West, Middle and Montaza zones, that follow emergency plan and maintain emergency material as much as possible.

This might be related to several reasons, first the committee personnel in all observed schools consists mainly of teachers, social workers and school principals, but actual work and activities was actually performed by one person responsible for all school emergency activities who usually obtained training without transmitting his knowledge to other committee members. Those committee personnel did not perform any drill for students in all assessed schools, and they usually were responsible for modifying the evacuation plan and keeping it locked in a safe place, usually done for quality visit checkout or for inspection. The other reason might be that most committee personnel were unsatisfied with sharing in the committee because they recognized committee work as burden more than thinking of it's importance for protection and saving the lives of students and themselves.

In addition, results of this study illustrated that the majority of the study sample obtained unsatisfactory score for their knowledge and practice related to disaster and disaster management. The low score reflects deficiencies in all assessed aspects of information and practice; lack of knowledge, lack of training and absence of motivation. Findings of this study were in harmony with Mamogale (2011) who reported that the vast majority of his study sample had average and lower knowledge score about hazards, disaster preparedness, planning, public education and training ${ }^{(24)}$.

\section{Conclusion}

Based on the findings of this study, it could be concluded that all assessed schools had disaster and crisis management plan, in spite of the majority of the crisis and disaster committee members were not oriented with its content, never dealt with any emergency and never checked on the emergency equipment placed in the plan. Most significantly is that, the available plans were not flexible for different situations of the different schools, were not reviewed annually, and no drill or rehearsal was applied.

The majority of the study sample obtained unsatisfactory score for their knowledge and practice related to disaster and disaster management. The low score reflects deficiencies in all assessed aspects of information; lack of knowledge, lack of training and absence of motivation.

\section{Recommendations}

The following recommendations can be made in the light of the current study results:

- Cooperation agreements between educational institutions and civil society organizations should be promoted towards achieving comprehensive standardized national preventive strategies for required safety measures in the schools.

- Disaster and crisis committee's members' cooperation from all educational zones should be encouraged through regular meetings in order to discuss school hazards, crisis and disasters outbreak and 
methods of response, applying physical drills and conducting training to teachers.

- School curricular materials concerning crisis and disasters management should be revised to include all recent information on crises and disaster risk reduction in the schools, methods of dealing with it, and having a drill or rehearsal at least once each academic semester.

- Training programs, manuals and media should be developed in order to empower school committee members and teachers to provide proper educational messages and conduct practical exercises. 
Table (1): Socio-demographic characteristics and general information about crises and disaster committees in all assessed schools.

\begin{tabular}{|c|c|c|c|}
\hline \multicolumn{2}{|c|}{ General information about disaster and crisis committees } & No. & $\%$ \\
\hline Age & $\begin{array}{l}\text { Min - Max } \\
\text { Mean } \pm \text { SD }\end{array}$ & \multicolumn{2}{|c|}{$\begin{array}{c}23-59 \\
46.54 \pm 7.52\end{array}$} \\
\hline \multirow[t]{2}{*}{ Sex } & Male & 139 & 66.2 \\
\hline & Female & 71 & 33.8 \\
\hline \multirow[t]{3}{*}{ Level of Education } & Post graduate & 3 & 1.4 \\
\hline & Graduate & 140 & 66.7 \\
\hline & Diploma & 67 & 31.9 \\
\hline \multirow{9}{*}{$\begin{array}{l}\text { Committee members' } \\
\text { position at their schools }\end{array}$} & Administrative employee & 1 & 0.5 \\
\hline & Social Worker & 7 & 3.3 \\
\hline & Nurse & 8 & 3.8 \\
\hline & Psychologist & 2 & 1.0 \\
\hline & Teacher & 167 & 79.5 \\
\hline & Head Master & 8 & 3.8 \\
\hline & Assistant Head Master & 8 & 3.8 \\
\hline & Workers & 3 & 1.4 \\
\hline & Lab technician & 6 & 2.9 \\
\hline \multirow{4}{*}{$\begin{array}{l}\text { Duration of membership } \\
\text { in the committee }\end{array}$} & $<1$ year & 73 & 34.8 \\
\hline & -4 years & 104 & 49.5 \\
\hline & - 10 years & 30 & 14.3 \\
\hline & $>10$ years & 3 & 1.4 \\
\hline \multirow{8}{*}{$\begin{array}{l}\text { Topics of training } \\
\text { attended: } * *\end{array}$} & Evacuation plan & 111 & 52.9 \\
\hline & Using alarm system & 38 & 18.1 \\
\hline & First Aid & 74 & 35.2 \\
\hline & C.P.R & 24 & 11.4 \\
\hline & Use of fire extinguisher & 114 & 54.3 \\
\hline & Chemical substance precautions & 12 & 5.7 \\
\hline & Fire management & 52 & 24.8 \\
\hline & Disaster Management & 52 & 24.8 \\
\hline \multirow{3}{*}{$\begin{array}{l}\text { Evacuation } \\
\text { training/term for } \\
\text { students }\end{array}$} & None & 110 & 52.3 \\
\hline & One & 77 & 36.7 \\
\hline & Two \& more & 23 & 11.0 \\
\hline
\end{tabular}

** More than one answer was given 
Table (2): School building and classroom characteristics as observed.

\begin{tabular}{|c|c|c|}
\hline \multirow{2}{*}{ Observed Items } & \multicolumn{2}{|c|}{ Present } \\
\hline & No. & $\%$ \\
\hline \multicolumn{3}{|l|}{ School building characteristics $(\mathrm{N}=21)$} \\
\hline Engineering drawing of the school & 15 & 71.4 \\
\hline Emergency exit stairs & 17 & 81.0 \\
\hline Minimal two entrances to the school & 16 & 76.2 \\
\hline Fence around the school & 21 & 100 \\
\hline $\begin{array}{l}\text { Building design provides the required utilities } \\
\text { for people with disabilities }\end{array}$ & 5 & 23.8 \\
\hline Safe stairswith handrails & 12 & 57.1 \\
\hline $\begin{array}{l}\text { Electricity hazardous areas are separate and } \\
\text { closed }\end{array}$ & 12 & 57.1 \\
\hline Fixed electricity contact & 12 & 57.1 \\
\hline $\begin{array}{l}\text { "No smoking" sign in all parts of the school } \\
\text { building }\end{array}$ & 11 & 52.4 \\
\hline Emergency exit signs & 7 & 33.3 \\
\hline Health awareness posters & 21 & 100 \\
\hline $\begin{array}{l}\text { Booklet explaining safety, security and } \\
\text { evacuation procedures }\end{array}$ & 0 & 00.0 \\
\hline Disposed waste daily & 19 & 90.5 \\
\hline \multicolumn{3}{|l|}{ Classrooms characteristics $(\mathrm{N}=21)$} \\
\hline Clean with wastepaper basket & 21 & 100 \\
\hline Natural lighting & 15 & 71.4 \\
\hline Artificial light & 4 & 19.0 \\
\hline Well ventilated & 15 & 71.4 \\
\hline Suitable size of chairs & 19 & 90.5 \\
\hline Curtains hung on windows & 0 & 00.0 \\
\hline Posters disseminate health awareness & 15 & 71.4 \\
\hline Safety slide placed on upper windows & 4 & 19.0 \\
\hline
\end{tabular}


Table (3): School crisis and disaster management plan characteristics and safety measures adopted at the observed schools.

\begin{tabular}{|c|c|c|}
\hline \multirow{2}{*}{$\begin{array}{l}\text { Crisis \& disaster management plan/ } \\
\text { Safety measures }\end{array}$} & \multicolumn{2}{|c|}{ Present } \\
\hline & No. & $\%$ \\
\hline Evacuation plan revised annually & 10 & 47.6 \\
\hline Plan deals with various situations & 4 & 19.0 \\
\hline $\begin{array}{l}\text { Names of team members' in disasters committee clearly } \\
\text { shown in the plan }\end{array}$ & 6 & 28.6 \\
\hline Determined equipment placed in the evacuation plan & 14 & 66.7 \\
\hline Identify evacuation routes and assembling areas in the plan & 12 & 57.1 \\
\hline Train students on the evacuation & 12 & 57.1 \\
\hline Plan distributed in different areas of the school & 10 & 47.6 \\
\hline Signsof emergency exits distributed & 17 & 81.0 \\
\hline Exit routes free from obstructions & 18 & 85.7 \\
\hline Emergency phone numbers documented for easy access & 3 & 14.3 \\
\hline Fire alarm works well & 14 & 66.7 \\
\hline Fire alarm could be heard in all the school area & 13 & 61.9 \\
\hline Reporting personspresent in the assembling area & 12 & 57.1 \\
\hline First aid kit present in the assembling area & 14 & 66.7 \\
\hline First aid kit available inside every classrooms & 6 & 28.6 \\
\hline First aid kit available inside school clinic & 20 & 95.2 \\
\hline $\begin{array}{l}\text { First aid kit had complete material and ready to use for } \\
\text { emergency }\end{array}$ & 20 & 95.2 \\
\hline Register visitors daily & 14 & 66.7 \\
\hline
\end{tabular}


Disaster Management Measures

Table (4): Percent score of the crisis and disaster committee members' correct knowledge about disaster and disaster management.

\begin{tabular}{|c|c|c|c|c|}
\hline \multirow{3}{*}{ Disaster and disaster management topics } & \multicolumn{4}{|c|}{ Knowledge score categories (N=210) } \\
\hline & $\begin{array}{c}\text { Satisfactory } \\
(\mathbf{5})\end{array}$ & $\begin{array}{c}\text { Unsatisfactory } \\
(\mathbf{2 0 5})\end{array}$ & \multirow[t]{2}{*}{$x^{2}$} & \multirow[t]{2}{*}{$\mathrm{P}$} \\
\hline & $\%$ & $\%$ & & \\
\hline Definition of disaster & 60.0 & 62.4 & 0.012 & 0.911 \\
\hline Types of natural disasters & 100 & 82.9 & 1.024 & 0.311 \\
\hline Types of man-made disasters & 100 & 94.6 & 0.283 & 0.595 \\
\hline Phases of disaster management & 100 & 70.7 & 2.049 & 0.152 \\
\hline General information about fire and its management & 40.0 & 4.40 & 12.469 & $0.000 *$ \\
\hline Risk of fire & 60.0 & 19.0 & 5.122 & $0.024 *$ \\
\hline Types of fire & 80.0 & 27.8 & 6.452 & $0.011 *$ \\
\hline Mean of fire fighting & 100 & 75.1 & 1.643 & 0.200 \\
\hline Fire fighters theory & 60.0 & 46.3 & 0.366 & 0.545 \\
\hline Contents of the first aid kit. & 100 & 75.1 & 1.643 & 0.200 \\
\hline Goal of crises and disasters committee. & 100 & 61.5 & 3.089 & 0.079 \\
\hline Responsibilities of the crises \& disasters team & 100 & 60.5 & 3.216 & 0.073 \\
\hline Disaster management before the crisis & 100 & 51.2 & 4.656 & $0.031 *$ \\
\hline Disaster management during the crisis & 100 & 48.8 & 5.122 & $0.024 *$ \\
\hline Disaster management after the crisis & 100 & 49.3 & 5.025 & $0.025^{*}$ \\
\hline
\end{tabular}

* Significant at $\mathrm{P} \leq 0.05$

Satisfactory $\geq 85 \%$ 
Disaster Management Measures

Table (5): Correct answers of the crisis and disaster committee members about disaster and disaster management according to educational zones.

\begin{tabular}{|c|c|c|c|c|c|c|c|c|c|}
\hline \multirow{3}{*}{ Disaster and disaster management topics } & \multicolumn{9}{|c|}{ Educational Zones } \\
\hline & $\begin{array}{c}\text { West } \\
(30)\end{array}$ & $\begin{array}{l}\text { East } \\
(30)\end{array}$ & $\begin{array}{c}\text { Middle } \\
(30)\end{array}$ & $\begin{array}{c}\text { Montaza } \\
(30)\end{array}$ & $\begin{array}{c}\text { Amria } \\
(30)\end{array}$ & $\begin{array}{c}\text { Borg } \\
\text { Arab } \\
(30)\end{array}$ & $\begin{array}{c}\text { El } \\
\text { Gomruk } \\
(30)\end{array}$ & \multirow[t]{2}{*}{$\chi^{2}$} & \multirow[t]{2}{*}{$P$} \\
\hline & $\%$ & $\%$ & $\%$ & $\%$ & $\%$ & $\%$ & $\%$ & & \\
\hline Definition of disaster & 60.0 & 63.3 & 56.7 & 53.3 & 93.3 & 63.3 & 46.7 & 16.964 & $0.009 *$ \\
\hline Types of natural disasters. & 86.7 & 83.3 & 80.0 & 83.3 & 80.0 & 100 & 70.0 & 10.560 & 0.103 \\
\hline Types of man-made disasters. & 93.3 & 86.7 & 93.3 & 90.0 & 100 & 100 & 100 & 10.553 & 0.103 \\
\hline Phases of disaster management. & 73.3 & 60.0 & 70.0 & 70.0 & 60.0 & 70.0 & 96.7 & 19.508 & 0.077 \\
\hline General information about fire and its management. & 56.7 & 50.0 & 60.0 & 53.3 & 73.3 & 83.3 & 66.7 & 10.909 & 0.091 \\
\hline Risk of fire & 40.0 & 16.7 & 30.0 & 16.7 & 00.0 & 6.70 & 30.0 & 22.500 & $0.001 *$ \\
\hline Types of fire & 16.7 & 10.0 & 3.30 & 6.70 & 00.0 & 00.0 & 00.0 & 14.582 & $0.024 *$ \\
\hline Mean of fire fighting & 76.7 & 63.3 & 86.7 & 56.7 & 93.3 & 56.7 & 96.7 & 63.011 & $0.000 *$ \\
\hline Fire fighters theory & 66.7 & 73.3 & 46.7 & 30.0 & 46.7 & 40.0 & 23.3 & 23.839 & $0.001 *$ \\
\hline Contents of the first aid kit. & 73.3 & 60.0 & 90.0 & 70.0 & 66.7 & 93.3 & 76.7 & 14.399 & $0.025 *$ \\
\hline Goal of crises and disaster committee. & 40.0 & 83.3 & 86.7 & 80.0 & 43.3 & 43.3 & 60.0 & 32.873 & $0.000 *$ \\
\hline Responsibilities of the crises \& disasters team. & 30.0 & 73.3 & 80.0 & 76.7 & 36.7 & 73.3 & 60.0 & 31.192 & $0.000 *$ \\
\hline Disaster management before the crisis. & 50.0 & 53.3 & 56.7 & 73.3 & 43.3 & 70.0 & 20.0 & 22.909 & $0.001 *$ \\
\hline Disaster management during the crisis. & 30.0 & 46.7 & 46.7 & 40.0 & 80.0 & 73.3 & 33.3 & 26.933 & $0.000 *$ \\
\hline Disaster management after the crisis. & 46.7 & 63.3 & 50.0 & 43.3 & 56.7 & 40.0 & 53.3 & 4.648 & 0.590 \\
\hline
\end{tabular}


Disaster Management Measures

Table (6): Knowledge of the crisis and disaster committee members about their committee duties according to school stages, school districts, and committee members' age groups, gender and level of education.

\begin{tabular}{|c|c|c|c|c|c|c|}
\hline \multirow{3}{*}{ Items } & & \multicolumn{5}{|c|}{ Disaster committee personal ( $\mathrm{N}=210)$} \\
\hline & & Principle (18) & $\begin{array}{c}\text { Teachers and } \\
\text { social worker } \\
(175)\end{array}$ & $\begin{array}{l}\text { Nurses } \\
(9)\end{array}$ & $\begin{array}{c}\text { Administrators } \\
\text { and technicians } \\
\text { (6) }\end{array}$ & $\begin{array}{c}\text { Security and } \\
\text { Safety (2) }\end{array}$ \\
\hline & & $\%$ & $\%$ & $\%$ & $\%$ & $\%$ \\
\hline \multirow{5}{*}{ School stages } & Primary & 85.7 & 61.7 & 66.7 & 66.7 & 00.0 \\
\hline & Preparatory & 50.0 & 50.0 & 100 & 50.0 & 00.0 \\
\hline & Secondary & 40.0 & 57.1 & 100 & 100 & 00.0 \\
\hline & Mixed & 50.0 & 63.0 & 00.0 & 00.0 & 50.0 \\
\hline & $\chi^{2}$ (P value) & $3.032(0.387)$ & $1.856(0.603)$ & $5.143(0.162)$ & $0.750(0.687)$ & ....... \\
\hline \multirow{8}{*}{ School district } & West & 80.0 & 57.9 & 75.0 & 50.0 & 00.0 \\
\hline & East & 83.3 & 57.1 & 100 & 100 & 00.0 \\
\hline & Middle & 100 & 69.2 & 100 & 100 & 00.0 \\
\hline & Montaza & 00.0 & 69.0 & 00.0 & 00.0 & 00.0 \\
\hline & Amria & 00.0 & 46.2 & 00.0 & 00.0 & 00.0 \\
\hline & Porg El Arab & 50.0 & 63.0 & 00.0 & 00.0 & 00.0 \\
\hline & El Gomrok & 00.0 & 37.0 & 00.0 & 100 & 50.0 \\
\hline & $\chi^{2}$ (P value) & $9.023(0.108)$ & $9.323(0.156)$ & $4.661(0.198)$ & $3.750(0.441)$ & ...... \\
\hline \multirow{5}{*}{$\begin{array}{l}\text { Committee members } \\
\text { age group }\end{array}$} & $20-29$ & 100 & 100 & 00.0 & 00.0 & 00.0 \\
\hline & $30-39$ & 00.0 & 61.1 & 50.0 & 00.0 & 00.0 \\
\hline & $40-49$ & 25.0 & 55.8 & 75.0 & 00.0 & 00.0 \\
\hline & $50-59$ & 69.2 & 55.7 & 100 & 4.0 & 100 \\
\hline & $\chi^{2}$ (P value) & $3.192(0.203)$ & $1.084(0.781)$ & $1.768(0.413)$ & $2.400(0.121)$ & $2.000(0.157)$ \\
\hline \multirow{3}{*}{$\begin{array}{c}\text { Committee members } \\
\text { gender }\end{array}$} & Male & 57.1 & 54.0 & 100 & 33.3 & 50.0 \\
\hline & Female & 63.6 & 65.3 & 75.0 & 100 & 00.0 \\
\hline & $\chi^{2}$ (P value $)$ & $0.076(0.783)$ & $1.852(0.174)$ & $0.321(0.571)$ & $3.000(0.083)$ & -..... \\
\hline \multirow{4}{*}{$\begin{array}{l}\text { Committee members } \\
\text { level of education }\end{array}$} & Diploma & 60.0 & 40.4 & 75.0 & 60.0 & 50.0 \\
\hline & Graduate & 61.5 & 63.2 & 100 & 100 & 00.0 \\
\hline & Post graduate & 00.0 & 66.7 & 00.0 & 00.0 & 00.0 \\
\hline & $\chi^{2}$ (P value) & $0.004(0.952)$ & $7.347(0.025)^{*}$ & $0.321(0.571)$ & $0.600(0.439)$ & ....... \\
\hline
\end{tabular}


Disaster Management Measures

Table (7): Percent score of the crisis and disaster committee members practice concerning activities and safety measures.

\begin{tabular}{|c|c|c|c|c|}
\hline \multirow{3}{*}{ Practice domains } & \multicolumn{4}{|c|}{$\begin{array}{l}\text { Practice score categories } \\
\qquad \mathrm{N}=210\end{array}$} \\
\hline & $\begin{array}{c}\text { Satisfactory } \\
(\mathrm{N}=16)\end{array}$ & $\begin{array}{c}\text { Unsatisfactory } \\
(\mathrm{N}=194)\end{array}$ & \multirow{2}{*}{$x^{2}$} & \multirow{2}{*}{$\mathrm{P}$} \\
\hline & $\%$ & $\%$ & & \\
\hline Activities done by the committee & 37.5 & 85.6 & 5.796 & $0.016^{*}$ \\
\hline Inspection done for the school environment & 87.5 & 44.8 & 6.333 & $0.012^{*}$ \\
\hline Frequency of inspection done per term & 50.0 & 85.6 & 13.164 & $0.000^{*}$ \\
\hline Inspection report to responsible members & 4.38 & 69.1 & 1.119 & 0.290 \\
\hline Maintenance done according to inspection result & 100 & 40.7 & 10.445 & $0.001 *$ \\
\hline Had Emergency evacuation plan & 31.2 & 80.9 & 1.370 & 0.242 \\
\hline Measures adopted during evacuation & 81.2 & 65.5 & 13.677 & $0.000 *$ \\
\hline Hazards present at the school & 56.2 & 60.3 & 1.676 & 0.195 \\
\hline Event of a earthquake in case out of the building & 75.0 & 64.4 & 9.700 & $0.002 *$ \\
\hline In case of fire due to electricity & 81.2 & 44.3 & 3.961 & $0.047^{*}$ \\
\hline In case of fire on one of the school buildings & 62.5 & 74.2 & 9.769 & $0.002 *$ \\
\hline In case of fire catch on a person & 87.5 & 59.8 & 13.430 & $0.000^{*}$ \\
\hline In case of armed robbery or shooting & 68.8 & 53.6 & 2.960 & 0.085 \\
\hline In case of epidemic or infectious diseases & 50.0 & 75.3 & 4.822 & $0.028 *$ \\
\hline
\end{tabular}




\section{References}

1. Disaster and emergencies definitions: WHO/EHA PanAfrican Emergency Training Centre, Addis Ababa; March 2002. Available at: http://apps.who.int/disasters/repo/7656. pdf. [Retrieved on: June 30th, 2015].

2. Carlson K, AACN Advanced Critical Care Nursing. St. Louis: Saunders/Elsevier; 2009.

3. The role of the school nurse: National Association of school Nurses (NASN); 2011.Available

at:https://www.nasn.org/PolicyAdvocac $\mathrm{y} /$ PositionPapersandReports/NASNPosi tionStatementsFullView/tabid/462/Artic leId/87/Role-of-the-School-Nurse-

Revised-2011. [Retrieved on: May $25^{\text {th }}$, 2015].

4. District disaster management plan. District disaster management authority: Sindhudurg disaster management programme. Government of Maharashtra; 2011. Updated 2015-2016. Available at:

http://sindhudurg.nic.in/site/htmldocs/p df/disaster.pdf. [Retrieved on: June $30^{\text {th }}$ 2015].

5. Clark M, Community Health Nursing, Pearson education. $5^{\text {th }}$ ed. Toronto, Canada: Pearson Education Canada; 2008.

6. Petal M. Risk RED: disaster prevention for schools. Guidance for Education Sector Decision-Makers. Consultation version, November 2008. International Strategy for Disaster Reduction Thematic Platform for Knowledge and Education. Geneva: UNISDR; 2009. Available at:http://www.unisdr.org/files/7556_734 4DPforSchoolssm1.pdf. [Retrieved on: June $30^{\text {th }}, 2015$ ].

7. Vos F, Rodriguez J, Below R, Sapir G. Annual disaster statistical review
2009; The numbers and trends. Belgium: Centre for Research on the Epidemiology of Disasters (CRED), WHO, UCL, CiacoImprimerie, Louvain-la-Neuve; 2009.Available at: http://www.cred.be/sites/default/files/A DSR_2010.pdf. [Retrieved on: June $30^{\text {th }}$ 2015].

8. Singh D, Niwas R, Singh R, Dhankhar $S$, Khichar M. Manual on disaster management. India: Dept of Agril Meteorology, CCS Haryana Agril University; 2010. Available at: http://www.hau.ernet.in/coa/agroment/a ssets/agmetdm.pdf. [Retrieved on: June $\left.30^{\text {th }}, 2015\right]$.

9. Eriksen M. UN prepares Egyptian children for natural disasters: Egypt Independent;2013. Available at: http://www.egyptindependent.com/node 1504701. [Retrieved on: June $30^{\text {th }}$, 2015].

10. Model school crisis management plan. Virginia Department of Education: Division of Special Education and Student Services; 2002. Available at: http://www.doe.virginia.gov/support/saf ety_crisis_management/emergency_cris is_management/model_plan.pdf. [Retrieved on: May 20 ${ }^{\text {th }}, 2015$ ].

11. Role of the School Nurse in Providing School Health Services. Council on School Health. American Academy of Pediatrics; 2008. Available at: http://www.healthvermont.gov/local/sch ool/documents/AAProleof

SchoolinProvidingschoolhealthservices. pdf. [Retrieved on: May 20 ${ }^{\text {th }}, 2015$ ].

12. National Association of school Nurses (NASN). Maryland; 2012. Available at: http://www.nasn.org/portals/0/binder_p apers reports.pdf. [Retrieved on: June $\left.20^{\text {th }}, 2014\right]$.

13. Hess F. School nurse disaster response. Pinnacle Health System. PINNACLE HEALTH. October $8^{\text {th }}, 2012$. Available 
at:

http://www.pinnaclehealth.org/pinnacle/ media/Newsletters-Print /References School-Nurse-Disaster-Response.pdf [Retrieved on: June $30^{\text {th }}, 2015$ ].

14. Saleh L. Development of standards for school health nursing practice in Alexandria. Doctor Thesis. Faculty of Nursing, Alexandria University; 2007.

15. Vos F, Rodriguez J, Below R, GuhaSapir D. Annual disaster statistical review 2010. Belgium: The numbers and trends, Centre for Research on the Epidemiology of Disasters, CiacoImprimerie, Louvain-la-Neuve; 2010.Available at: http://www.cred.be/sites/default/files/A DSR_2010.pdf. [Retrieved on: June $\left.30^{\text {th }}, 2015\right]$.

16. Comprehensive school safety guide. Homeland Security and Emergency Management (HSEM.): Keeping Mennesota Ready; 2009. Available at: https://dps.mn.gov/divisions/hsem/mnschool-safetycenter/Documents/Comprehensive\%20S chool\%20Safety\%20Guide.pdf. [Retrieved on: June 30 ${ }^{\text {th }}, 2015$ ]

17. David S, Fumiyo K. Disaster risk reduction in school curricula. Case Studies from Thirty Countries. Spain: UNICEF; 2012. Available at: http://www.unicef.org/education/files/D RRinCurriculaMapping30countriesFINAL.pdf. [Retrieved on: June $30^{\text {th }}, 2015$ ].

18. Durston S. Climate change adaptation and disaster risk reduction in the education sector. United Nations Children's Fund (UNICEF); 2012. Available at: http://www.unicef.org/cfs/files/UNICEF -ClimateChange-ResourceManual- lores-c.pdf. [Retrieved on: June $30^{\text {th }}$, 2015].

19. Wahlström M. Progress and Challenges in Disaster Risk Reduction: A contribution towards the development of policy indicators for the Post-2015 Framework on Disaster Risk Reduction. Geneva; United Nations 2014. Available at: http://www.unisdr.org/files/40967_4096 7progressandchallengesindisaste.pdf. [Retrieved on: June $30^{\text {th }}$, 2015].

20. Best practices guide for healthy schools: because healthy students and academic achievement go hand in hand. Available at:

http://www.coloradoedinitiative.org/wpcontent/uploads/2013/04/BestPractices GuideUpdatedPages.pdf. [Retrieved on: May $20^{\text {th }}, 2015$ ].

21. Helal H. Promotion of safety in primary schools. Doctor Thesis. Public Health. Faculty of Nursing, University of Alexandria; 2005.

22. Xaba M. A Holistic Approach to Safety and Security at Schools in South Africa. Meditranean J. of Social Sci, Rome, Italy; 2014; 5(20):1580-9.

23. Ali S, Abu-Eleoud A, Heybah S, Mohamed A. Implementation of an educational training program in first aid for newly graduated nursery school teachers at Zagazig city. ZJOHs 2010; 3(1): 20-9.

24. Mamogale H. Assessing disaster preparedness of learners and educators in Soshanguve North schools. Master Thesis, University of the Free State; 2011. Available at: http://natagri.ufs.ac.za/dl/userfiles/Docu ments/00002/2291 eng.pdf. [Retrieved on: June $\left.30^{\text {th }}, 2015\right]$. 